\title{
The Effect of Wet Cupping (Hijama) Toward The Changing of Body Immune System in Venous Blood of Healthy Person
}

\author{
Wita Asmalinda ${ }^{1}$ ), Ibrahim Edy Sapada ${ }^{2}$ \\ ${ }^{I}$ Midwifery Department of Health Polytechnic Ministry of Health Palembang \\ ${ }^{2}$ Siti Khadijah Institude of Health Science Palembang \\ e-mail: wita_asmalinda@yahoo.co.id ${ }^{\left.{ }^{*}\right)} ;$ ib_edys@yahoo.co.id ${ }^{2}$
}

\section{ARTICLE INFO}

\section{Article history:}

Received August 22, 2018

Revised November 23, 2018

Accepted November 25, 2018

\section{Keyword:}

Wet cupping

Leucocyte

Leucocyte differential count

*) corresponding author

DOI:http://dx.doi.org/10.30604/jika.v3i2.121

\begin{abstract}
A B S T R A C T
Our bodies have an immune system, composed of cells and tissues that make up the immunity. Immune responce is away that made the body to respond to stimulations from inside or outside the body. Changes in leucocyte and leucocyte differential count indicate a humoral and cellular immune response as a tolerance of homeostatic changes in the body. Wet cupping is a treatment efforts to restore the homeostasis of the immune system. The aim of this research to know the effect of Wet cupping (Hijamah) of body immune system in venous blood of healthy person. This study was an experimental clinical trial without comparison (pretest and posttest without control group design). This research is done at the Clinic Cupping Ibnu Sina Palembang for 21 days. The blood test was conducted at the center for Laboratory of Health (BBLK) South Sumatera region. The sample in this study were some adult women who meet the criteria of inclusion and exclusion. A sample size of 30 people. Measurement parameter had increase of leucocyte and leucocyte differential count. The data obtained in this study were then analyzed statistically using SPSS version 20, which included a homogeneity test sample using Shapiro wilk test, description analysis to know the mean value and standard deviation. There were significantly increased in the number of leucocyte, neutrophil, and monocyte after 8 hours of Wet cupping and there no significant increased of lymphocyte. There was significant reduction of eosinophil after Wet cupping. There was no change of basophil. Wet cupping can grow up the immune system.
\end{abstract}

This is an open access article under the CC-BY-SA license. 


\section{INTRODUCTION}

Our bodies have an immune system composed of cells and tissues that make up immunity (Lawrence, 2002). Changes in leucocyte number and leucocyte differential count indicates a humoral and cellular immune response as a tolerance of homeostatic changes in the body (Saputri, 2011; Sherwood, 2001). Wet cupping (Hijamah) is a treatment using glass or glass tube which process begins with a vacuum that aims to create negative pressure so as to cause a local dam on the surface of the skin, so that the injured tissue will release substances of inflammatory mediators, among others; histamine, bradykinin, serotonin and prostaglandin. Followed by injury/ syringe using a surgical blade/ lancet and lastly done vacuum again (blood letting) on the surface of the skin to remove blood and accommodated in a glass (glass tube) (Hennawy, 2004; El Sayed, 2013).

The inflammatory process, shedding and blood letting done on Wet cupping is considered as an expose stressor that will harm the body tissues so that will cause physical stress (Kadir, 2010). The general response to physical stress is to spur a series of reactions from the hypothalamic-pituitarycortex adrenal (HPA) system that produces adrenocorticotropin hormone and cortisol (corticosteroid) and the activating hypothalamic pituitary Sympathetic Adreno Medullary (SAM) system the sympathetic nervous system to secrete epinephrine, norepinephrine and dopamine (Nugraha, 2011). The hormone will activate macrophages and complementary and bone marrow systems (Kadir, 2010; Nugraha, 2011).

Wet cupping (Hijamah) is a treatment method that has been used in the treatment and treatment of various diseases such as: knee pain, blood disorders, treat inflammatory/ inflammatory pain, physical and mental relaxation, varices of the veins and tissue massage, hypertension, rheumatic disease, backache, migraine, anxiety or anxiety and general physical as well as mental problems (Hennawy, 2004). WHO has established 3 (three) requirements for Wet cupping to be recommended in public health service facilities, one of which is a benefit test.

The aim of this research in know the effect of Wet cupping (Hijamah) toward the changing of body immune system in venous blood of healthy person.

\section{METHODS}

This study was an experimental clinical trial without comparison (pretest and posttest without control group design). This research is done at the Clinic Bekam Ibnu Sina Palembang. Blood test were conducted at the Central Laboratory of Health (BBLK) South Sumatera region. Research time for 21 days. The population in this study were all adult women who perform cupping therapy at Clinic Bekam Ibnu Sina Palembang. The sample in this study were some adult women who meet the criteria of inclusion and exclusion. A sample size of 30 people.

Each sample that meets the inclusion and exclusion criteria is taken randomly until the desired number of samples. To all samples described the objectives, procedures, benefits and risks as samples in this study. After obtaining the approval of the sample then signed the informed consent to the respondent.

The research variables are: independent variable that is Wet cupping and dependent variable are leucocyte number and count leucocyte type. Treatment of research subjects, to minimize confounding factors, each subject was asked to sign a letter willing not to exercise and did not take supplement before the pretest blood ( 2 days before Wet cupping) and after treatment until before taken blood posttest ( 8 hours after Wet cupping). Equipment and materials used in this research are equipment and materials for Wet cupping are: glass cupping and handpump (pump), lancet (needle), scalpel, 
scissors, apron, gauze clamp (clamp pean) cloth duk, gloves (handscoen), facial mask (facemasker), bowl/ saucer, sterile gauze, cotton, tray, dustbin, table, chair and bed check. The difficulty of the availability of oxygen cylinders. Wet cupping material consists of: betadine (iodine), $70 \%$ alcohol, $\mathrm{H} 2 \mathrm{O} 2$ solution, olive oil and Black seed oil (Sarkosih, 2012; Widada, 2011), and venous blood test (leucocyte and leucocyte differential count): blood lancet, needle, syringe and bottle, (equipment and materials for manual leucocyte examination) hemocytometer, object glass and cover glass, microscope. Equipment and examination of leucocyte Sismex KX2 using automatic hematology analyzer.

\section{RESULTS AND DISCUSSION}

The results obtained are data before and 8 hours after Wet cupping. The resulting data is normally distributed for the number of leucocyte and monocyte where as neutrophil, lymphocyte and eosinophil data are not normally distributed, followed by the Wilcoxon test. Basophil data can't be analyzed because there is no change of value before and after Wet cupping.

Table 1.

Mean Age of Respondent

\begin{tabular}{lcc}
\hline Mean Age (Year) & n & \% \\
\hline $18-20$ & 24 & 80 \\
$21-22$ & 6 & 20 \\
\hline Total & $\mathbf{3 0}$ & $\mathbf{1 0 0}$ \\
\hline
\end{tabular}

Table 2.

Mean Leucocyte Type and Leucocyte Count Values Before and After Wet cupping

\begin{tabular}{lcccc}
\hline \multirow{2}{*}{ Variable } & \multicolumn{2}{c}{ Mean \pm SD } & \multicolumn{2}{c}{ Minimum-Maximum } \\
\cline { 2 - 5 } & Pre & Post & Pre & Post \\
\hline Leucocyte $(\mathrm{Sel} / \mu \mathrm{L})$ & $6,75 \pm 1,27$ & $8,22 \pm 1,55$ & $4,80-10,60$ & $5,50-13,20$ \\
Neutrophil $(\%)$ & $55,65 \pm 7,16$ & $58,03 \pm 6,86$ & $44-68$ & $45-75$ \\
Monocyte $(\%)$ & $7,26 \pm 2,93$ & $7,76 \pm 3,11$ & $3-16$ & $4-17$ \\
Lymphocyte $(\%)$ & $34,90 \pm 6,49$ & $36,20 \pm 6,73$ & $21-46$ & $17-47$ \\
Eosinophil $(\%)$ & $0,66 \pm 1,42$ & $0,20 \pm 0,80$ & $0,00-5,00$ & $0,00-4,00$ \\
\hline
\end{tabular}

Normality test results on the number of leucocyte before Wet cupping is normally distributed $(p=0.096)$ then continued with the Paired t-test

Table 3.

Differences in Mean Values of Leucocyte Before and After Wet cupping

\begin{tabular}{lcc}
\hline \multicolumn{1}{c}{ Variable } & Mean \pm SD & p value \\
\hline Leucocyte pre $(\mathrm{Sel} / \mu \mathrm{L})$ & $6,75 \pm 1,27$ & \\
Leucocyte post $(\mathrm{Sel} / \mu \mathrm{L})$ & $8,22 \pm 1,51$ & 0,001 \\
\hline
\end{tabular}

Result of normality test to amount of Neutrophil before Wet cupping is abnormally distributed $(\mathrm{p}=0,032)$ then continued with Wilcoxon-test
Table 4.

Differences in Mean Values of Neutrophil Before and After Wet cupping

\begin{tabular}{lcc}
\hline \multicolumn{1}{c}{ Variable } & Rerata \pm SD & p value \\
\hline Neutrophil pre $(\mathrm{Sel} / \mu \mathrm{L})$ & $55,56 \pm 7,16$ & \\
Neutrophil post $(\mathrm{Sel} / \mu \mathrm{L})$ & $58,03 \pm 6,86$ & 0,012 \\
\hline
\end{tabular}

Normality test result to monocyte count before Wet cupping is normally distributed ( $p$ $=0,208$ ) then continued with Paired t-test

Table 5.

Differences in Mean Values of Monocyte Before and After Wet cupping

\begin{tabular}{lcc}
\hline \multicolumn{1}{c}{ Variabel } & Mean \pm SD & p value \\
\hline Monocyte pre $(\mathrm{Sel} / \mu \mathrm{L})$ & $7,26 \pm 2,93$ & \\
Monocyte post $(\mathrm{Sel} / \mu \mathrm{L})$ & $7,76 \pm 3,11$ & 0,020 \\
\hline
\end{tabular}


Normality test results against the number of lymphocyte before Wet cupping is abnormally distributed $(\mathrm{p}=0.002)$ then continued with Wilxocon-test

Table 6.

Differences in Mean Lymphocyte Before and After Wet cupping

\begin{tabular}{lcc}
\hline \multicolumn{1}{c}{ Variable } & Mean \pm SD & p value \\
\hline Lymphocyte pre $(\mathrm{Sel} / \mu \mathrm{L})$ & $34,90 \pm 6,49$ & \multirow{2}{*}{0,258} \\
Lymphocyte post $(\mathrm{Sel} / \mu \mathrm{L})$ & $36,20 \pm 6,73$ & \\
\hline
\end{tabular}

Normality test result against eosinophil count before Wet cupping is abnormally distributed $(\mathrm{p}=0,000)$ then continued with Wilxocon-test

Table 7.

Differences in mean of Eosinophil Before and After Wet cupping

\begin{tabular}{lcc}
\hline \multicolumn{1}{c}{ Variable } & Mean \pm SD & p value \\
\hline Eosinophil pre $(\mathrm{Sel} / \mu \mathrm{L})$ & $0,66 \pm 1,42$ & \\
Eosinophil post $(\mathrm{Sel} / \mu \mathrm{L})$ & $0,20 \pm 0,80$ & 0,039 \\
\hline
\end{tabular}

\section{Effect of Wet cupping on Changes in the Number of Leucocyte}

From the statistical test to the number of leucocyte found the average value of leucocyte count after 8 hours with an increase of $1,13 \%$. The results of this study are in line with the research conducted by Khalil (2013), there was a significant increase in the number of leucocyte after 1 week of Wet cupping.

This is in line with the opinions of other researchers that the increased number of leucocyte is protective against physical stress due to Wet cupping. This increase is due to epinephrine and norepinephrine being released into the plasma causing marked physiological effects on the heart rate and vasomotor tone that eventually form the pattern of blood flow through the spleen tissue and leucocyte circulation (Irianri, 2008).

An increase in the number of leucocyte after Wet cupping is in normal vulnerability, which aims to restore the homeostasis of the immune system. In conditions of decreased leucocyte caused by excessive physical activity, lack of rest, eating foods containing preservatives and artificial sweeteners, are exposed to free radicals from continuous vehicle fumes and plants, it is recommended to treat Wet cupping. According to research (Widada, 2011) regular Wet cupping treatment is thought to stimulate cellular immune work so that the immune system reveals which ultimately improves health and fitness.

\section{Wet cupping Effect on The Number of Neutrophil Changes}

The statistical test of the mean value of neutrophil count increased significantly after Wet cupping. The results of this study are in line with the research conducted by Khalil (2013) there is a significant increase in the average number of neutrophil after 1 week Wet cupping.

Negative pressure on the surface of the skin, injuries and blood letting on the treatment Wet cupping provides a non-specific immune response that is an inflammatory reaction that is a rapid reaction to tissue damage, which is very useful for the body's defense, because the inflammatory reaction can prevent damage to other tissues and accelerate healing process. In the immune system the increase in the number of neutrophil cells as the first response of the body's defense system in the face of stimulation from outside the body in the form of phagocytosis process. In the immune system, neutrophil are the most leucocyte cells in the blood. Neutrophils will migrate throughout the body, mutually activating each other with other immune cells (Jasmika, 2011; Guyton and Hall, 2012)

Allegedly within a few hours after the inflammation begins, a large amount of neutrophils in the blood will invade the inflamed region due to the negative pressure of Wet cupping, The increase in the number of neutrophils after 8 hours of Wet cupping is caused by neutrophils activated by 
macrophage cells in the skin tissue, where the points of Wet cupping so that neutrophils in the blood are immediately mobile to the inflamed tissues to phagocytosis damaged cells and dead cells from treatment Wet cupping.

This increase is also due to the bone marrow that stores the neutrophil reserves activated by epinephrine and norepinephrine and dopamine secreted by the adrenal glands from a series of reactions of the hypothalamus-pituitary- sympatheticadreno- medullary (SAM) system and the hypothalamus-pituitary-cortex adrenal (HPA) so the bone marrow will release a deposit of neutrophils into the blood circulation (Kadir, 2010; Nugroho, 2011)

\section{Effect of Wet cupping on The Number of Monocyte Changes}

The statistical test results on the number of monocyte cell mean a significant increase. This result is in accordance with the study (Widada, 2011), there is a significant increase on the average number of macrophage cells (monocyte) after 15 days of Wet cupping. Monocyte cells have the same role with neutrophil cells is the function of phagocytosis. The monocyte period in the blood is 10-20 hours, before wandering through the capillary membrane into the tissues. After about a period of 8 hours, the monocyte enlarges into macrophage. This macrophage digests alien cells, damaged cells and dead cells (Widada, 2011). The increase in the number of monocyte cells is thought to be due to monocyte cells (macrophage) in the tissues and in the blood carrying out the phagocytosis function together with neutrophil cells. Excessive monocyte cells will produce cytokines that play a role in inflammatory reactions namely TNF- $\alpha$, Interleukin-1, Interleukin-3 and Interleukin-6, which serve as a signal between cells to form communication networks in the immune response. This cytokine works autocrine, in adjacent cells (paracrine) and works endocrine in the blood circulation. Furthermore, this immune product will activate the bone marrow to release monocyte deposits. An increase in the number of monocyte is also intended to produce Interleukin-1 which plays a role in activating $\mathrm{T}$ cells, $\mathrm{CD} 4+$ to produce Interleukin-2 which plays a role in $\mathrm{T}$ cell differentials to produce memory $\mathrm{T}$ cells.

\section{Effect of Wet cupping on the number of Lymphocyte Changes}

The statistical test results on the average number of lymphocyte cells increased although not significant. This result reinforces the results of the research by Widada (2011) where there was a significant increase in mean CD8+ $\mathrm{T}$ cell (killer cell) after 15 days of Wet cupping, but unlike the mean number of lymphocyte in the research conducted by Mahdavi (2013) decreased lymphocyte cell after 2 weeks Wet cupping, not significant.

Lymphocyte play a role in specific body defense. Called specific because it is only done by lymphocyte cells (Widada, 2011). Lymphocyte play a role in cell-mediated immune or $\mathrm{T}$ cell immunity and humoral immunity or B cell immunity (antibodies) (Lawrence, 2002). In people with lymphocyte deficiency or lymphocyte cells damaged by radiation or chemicals can not form a specific immunity (Irianri, 2008). Lymphocytes are most commonly found in the lymph nodes and lymphoid tissues such as the spleen, gastrointestinal submucosa, thymus and bone marrow. In lymphoid tissues other than lymphocytes there are also macrophages (Guyton and Hall, 2012). Most activating organisms will be phagocytosed by macrophages and then their antigenic products are released into the macrophage. Macrophage then transport these antigens directly to the lymphocyte leading to the activation of specific lymphocytic clones. In addition, macrophages also secrete a special activating agent that promotes growth and reproduction of special lymphocytes (Irianri, 2008). 
The increase in the number of lymphocyte that are not significant in the number of lymphocyte is likely due to the formation of lymphocyte cells are not as fast as neutrophil and monocyte cells on the mechanisms of inflammation and physical stress. The study sample was the first person in Wet cupping because acquired immunity did not arise until the body was first stimulated by Wet cupping action. Lymphocyte have a need for activation. $\mathrm{T}$ lymphocyte cell activation requires the delivery of intrasitoplasmic signals. After developing in the bone marrow, then to the thymus gland and eventually circulate in the blood. The process for this specific immune formation has a fairly long process, takes weeks, months to years.

\section{Effect of Wet cupping on the number of Eosinophil}

The statistical test on the mean eosinophil count decreased significantly after Wet cupping treatment. The results of this study are in line with the results of the research by Mahdavi (2013), where there is a decrease in the number of eosinophil after 2 weeks Wet cupping although the decrease is not significant.

Normal amount of eosinophil is about 2 percent of all blood leucocyte. Eosinophils are weak phagocytic cells and show chemotaxis phenomena, but when compared with neutrophil, the role of eosinophil as nonspecific body defenses is questionable. Eosinophils are produced in large numbers in patients with parasitic infections (Irianri, 2008).

The eosinophil cell contains profibrinolysis which plays a role in maintaining blood and clotting (Effendi, 2003). The main function of eosinophil is detoxification of both foreign proteins that enter the body and toxins produced by bacteria and parasites. Eosinophil have a special tendency to congregate in tissues where allergic reactions such as peribronchial lung tissue of asthma patients and in skin after skin are allergic (Irianri, 2008).

The decrease in eosinophil count is thought to be due to stimulation of exposure stressors after Wet cupping, causing physical stress, causing increased secretion of the hormone cortisol by the adrenal cortex. This hormone results in a decrease in the amount of eosinophil in the blood (eosinophilia). This decrease in eosinophil count is also due to Interleukin-10 activity on Interleukin-5 regulation in eosinophil inflammatory reaction to accelerate eosinophil death, but until now it is not known clearly the cause of eosinophil decrease, so it is necessary to investigate further mechanism happened decrease the eosinophil count. According to researchers this result can be recommended that Wet cupping is not harmful for asthma patients and skin diseases as it is proven to decrease the amount of eosinophil.

\section{Effect of Wet cupping on the number of Basophil}

The number of basophil in this study did not change before and after Wet cupping. As is known basophil cell function in the blood is similar to large mast cells that play a role in some types of allergic reactions, but in this study did not find any change in basophil cell value after Wet cupping. It is suspected that basophil cells do not play macrophage in the inflammatory response, so they do not affect the activity. The relation with this research has not known mechanism of no change of basophil count after Wet cupping so that need to be investigated further. According to the researchers, these results can be recommended that Wet cupping is safe to use because it does not cause allergic reactions.

\section{CONCLUSION AND RECOMMENDATION}

Based on the results of the analysis of the discussion, it can be concluded that there was a significant increase in the number of leucocyte, neutrophil and monocyte count 
after 8 hours Wet cupping. The number of lymphocyte increased by $0.01 \%$ after Wet cupping, this means an increase but not significant with the value of $p=0.258$. There was a significant decrease of eosinophil count after 8 hours Wet cupping with $\mathrm{p}$ value $=0,039$ with decrease of $30,87 \%$ and the basophil count after 8 hours Wet cupping not change.

This study needs to be continued because it is only revealed the effect of Wet cupping on the cellular level immune system, has not been able to describe the immune system completely, it is advisable further studies at the biomolecular level of the cytokine levels contributed to inflammatory reactions such as TNF- $\alpha$, Interleukin 1,3,6 and Interferon, the parameters of cytokine levels that contributed to the growth and differentiation of specific CD4+ $\mathrm{T}$ cells of Interleukin-2 and Interleukin-10 which plays a role in the acceleration of apoptosis of eosinophil cells.

\section{REFERENCE}

Ahmadia, A., Farhadia, K. and Schwebelb, D.C. (2009). The Effectiveness of Wet cupping for Nonspesific Low Back Pain in Iran: A Randamized controlled trial. BMC Complementary Therapies and Alternative Medicine 17, 9-15.

Amira, OC., and Okubadejo, N.U (2007). Frequency of Complementary and Alternative Medicine Utilization in Hipertensive Patiens Attending an Urban Tertiary Care Centre in Nigeria. BMC Complementary and Alternative Medicine 7, 30-35.

Bilal, Rafeeq, Ahmed and Afroz. (2011). Parsial Evaluation of Tecnique Used in Cupping Therapy. Journal of Basic and Applied Science 7(1), 65-68.

El Sayed, Mahmoud and Nabo. (2013). Methods of Wet cupping Therapy (Al-
Hijamah): In Light of Modern Medicine and Prophertic Medicine. Altern Integ Med 2 (3): 1-16.

Guyton and Hall.(2012) Text Book Physiology Medicine (Eds 11th). Jakarta: EGC.

Hennawy. (2004). Cupping Therapy and Infertility. Available at http://www.obgyn.net, browsing on 10 November 2016).

Irianri dan Ardinata. (2008). The Effectiveness of Physical Activity Medium in Leucocyte and Differential Count on the poeple were not properly trained. Journal Health magazine of Nusantara 41(4), 259-267.

Ishartadianti. (2010) Peranan TNF, $I L-1$ dan IL-6 pada Respon Imun terhadap Protozoa. Jurnal Kesehatan Universitas Wijaya Kusuma. Surabaya

Kadir, A. (2010). The Change of Hormone to Stress Jurnal kesehatan Universitas Wijaya Kusuma 2(1), 32-39.

Khalil, Al-qaoud and Shaqqour. 2013. Investigation of selected Immunocytogenetic Effects of Wet cupping in Healthy Men. Journal Spatulla DD 3(2), 51-57

Lawrence, Derek, A., Willoughby and W. Gilroy. et al. (2002). AntiInflammatory Lipid Mediators and Insight Into. The Resolution of Inflammation Nature Review 2, 21-27.

Mahdavi, Ghazanfari, Aghajani, Danyali and Naseri, et al. (2013). Evaluation of the effects of Traditional

Cupping on the Biochemical, Hematological and Immunological Factors of Human Venous Blood. Journal Compendium of Essays on Alternative Therapy 7, 68-88.

Notoatmodjo. (2005). Metodologi Penelitian Kesehatan (Edisi Revisi). Jakarta: Rineka Cipta. 
Nugroho, HSW. (2013). Laboratorium Klinik

I: Pemeriksaan Hematologi. Diunduh dari

statistic.schoolreck.com/files/25632/33

3288 tanggal 3 November 2016)

Nugroho, Pujo and Nurcahyo. (2011). Physiology and Pathophysiology dan Patofisiologi of Axis HipotalamusHipofisis-Adrenal. Jurnal Anastesional Indonesia 3(2), 132143.

Rizal. (2012). Pengaruh Bekam terhadap Respon Ketahanan Tubuh. Diunduh dari bekamjogja.Wordpress,com tanggal 2 Desember 2016.

Saputri, Dyah, and Abdulgani. (2011). The Leucocyte and Differential Count to Mencit (Mus Musculus) on Evaluation In Vivo Anti Cancer Ekstrak Spons Laut (Aaotos

Suberitoides). Article The Faculty of MIPA. Sepuluh Nopember Institute of Tehnologi, Surabaya.

Sarkosih. (2012). Identification of Patient Safety of Wet cupping at 4 (four) Territory of DKI Jakarta. Thesis. Faculty Public Health, Indonesian University.

Suryono. (2010). Penurunan kadar Kolesterol Total pada Pasien Hipertensi yang Mendapat Terapi Bekam di Klinik AnNahl Purwokerto. Jurnal Keperawatan Soedirman (The Soedirman Journal of Nursing) 5(2), 33-39.
Sastroasmoro dan Ismael. (2011). Dasardasar Metodologi Penelitian Klinis (Edisi ke-4). Jakarta: CV. Sagung Seto.

Sharaf, A.R. (2012). Penyakit dan Terapi Bekamnya: Dasar-dasar Ilmiah Terapi Bekam. Terjemahan oleh: Murtadlo, Saptorini (editor): Surakarta.

Sherwood and Laurelee. (2001). The Human Physiology from Cell to Cell. Jakarta: EGC

Sirois, F.M. (2008) Motivations for Consulting Complementary and Alternative Medicine Practitioners: A Comparison of Consumers from 19778 and 2005. BMC Complementary and Alterniative Medicine, 8(1), 16-23.

Soeroso. (2007). Sitokin. Jurnal Oftalmologi Indonesia. 5(3), 171-180.

Ullah, Yournis and Wali. (2007) An Investigation into Effect of Cupping Therapy for Anterior Knee Pain and Its Potential role in Health Promotion. The Internal Journal of Alternative Medicine, 4(1), 796-804.

Wanandi, S., Dewi, S. dan Paramita (2009). Ekspresi Relatif mRNA HIF-la pada Jantung, Otak dan Darah Tikus Selama Induksi Hipoksia Sistemik. Jurnal Makara Sains, 13(2), 185-188.

Widada. (2011). The Effect of Wet cupping on Increased Immune System: Cytotoxic $\mathrm{T}$ lymphocytes. Journal Forikes 2(4), 219-223. 